\title{
Optimal cultivation of Chlamydia requires testing of serum on individual species
}

\author{
Malhar Desai ${ }^{1,2}$, Huirong Zhang ${ }^{1}$ and Huizhou Fan ${ }^{1,2^{*}}$ (D)
}

\begin{abstract}
Objective: This report is a side product of experiments aimed at identifying serum for culturing obligate intracellular bacteria Chlamydia trachomatis and C. muridarum in mouse fibroblast L929 cells.

Results: Of five commercial serum samples tested, two showed optimal efficiencies at supporting growth of the human pathogen Chlamydia trachomatis as control fetal bovine serum, whereas two showed modest $~ 40 \%$ inhibitions in progeny production, and the remaining one showed a $20 \%$ inhibition. Three of the six sera poorly supported growth of the murine pathogen Chlamydia muridarum, resulting in $73-90 \%$ reduction in progeny formation. Most significantly, the one with the strongest (90\%) C. muridarum inhibition activity showed optimal C. trachomatis-supporting efficiency. These findings indicate that in laboratories that study multiple Chlamydia species, serum samples should be prescreened on a species basis. Considering Chlamydial biology and epidemiology, it may even be necessary to perform serum tests on a serovar- or strain-basis for studying some animal chlamydiae.
\end{abstract}

Keywords: Chlamydia trachomatis, Chlamydia muridarum, Fetal bovine serum, Serum test

\section{Introduction}

Animal serum serves as a rich source of growth factors for culturing animal cells [1] and intracellular pathogens requiring animal cells as hosts (e.g., [2-5]). Fetal bovine serum (FBS), which contains a large and diverse group of growth factors, has been a popular choice. However, the high costs of FBS (due to its limited supplies) and ethical concerns associated with its production have led some researchers to pursue using other alternatives to FBS, including newborn calf serum (NBCS, defined as serum collected from calves that are less than 10 days old) and horse serum [1-5].

Chlamydia is a genus of bacteria that replicates only inside host eukaryotic cells [6]. Chlamydia trachomatis and C. pneumoniae are common human pathogens. Whereas $C$. trachomatis is the number one sexually transmitted pathogenic bacterium [7], C. pneumoniae causes communicable respiratory infections [8]. Other Chlamydia species known as pathogens of animals including livestock may cause severe illness in humans after their contact with infected animals [9]. C. psittaci, cause of psittacosis, is the best example of zoonotic Chlamydia. C. muridarum is a mouse pathogen. Although $C$. muridarum infection in humans has never been documented, it is the most widely studied animal Chlamydia, owing to its capacity to model human chlamydial infections in mouse [10, 11].

Like many laboratories, our laboratory studies both $C$. trachomatis and C. muridarum. In an event evaluating commercial serum samples, we found differential effects of the sera on the two Chlamydia species. These findings mandate prescreening sera for individual species in laboratories that study multiple species.

\footnotetext{
*Correspondence: Huizhou.Fan@Rutgers.Edu

${ }^{1}$ Department of Pharmacology, Robert Wood Johnson Medical School,

Rutgers University, Piscataway, NJ, USA

Full list of author information is available at the end of the article
}

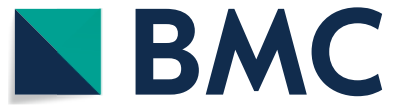

(C) The Author(s) 2020. This article is licensed under a Creative Commons Attribution 4.0 International License, which permits use, sharing, adaptation, distribution and reproduction in any medium or format, as long as you give appropriate credit to the original author(s) and the source, provide a link to the Creative Commons licence, and indicate if changes were made. The images or other third party material in this article are included in the article's Creative Commons licence, unless indicated otherwise in a credit line to the material. If material is not included in the article's Creative Commons licence and your intended use is not permitted by statutory regulation or exceeds the permitted use, you will need to obtain permission directly from the copyright holder. To view a copy of this licence, visit http://creativeco mmons.org/licenses/by/4.0/. The Creative Commons Public Domain Dedication waiver (http://creativecommons.org/publicdomain/ zero/1.0/) applies to the data made available in this article, unless otherwise stated in a credit line to the data. 


\section{Main text \\ Methods}

Animal serum

Samples of FBS, NBCS and ASC were supplied by American Type Culture Collection (ATCC), Atlantic Biologicals, Gemini Bio-products and Sigma Millipore. Prior to use, all serum samples as well as control FBS (Sigma Millipore) were subjected to heat inactivation $\left(56{ }^{\circ} \mathrm{C}, 30 \mathrm{~min}\right)$ to eliminate adverse effects of complements on chlamydiae [12].

\section{Evaluation of effects of serum on chlamydial growth}

Mouse fibroblast L929 cells were used as host for chlamydiae. They were grown as adherent cultures using the Dulbecco modified Eagle's medium containing $4.5 \mathrm{~g} / \mathrm{L}$ glucose and $0.11 \mathrm{~g} / \mathrm{L}$ sodium pyruvate (DMEM) and supplemented with $5 \%(\mathrm{vol} / \mathrm{vol})$ control FBS and gentamicin (final concentration: $10 \mu \mathrm{g} / \mathrm{ml}$ ). To evaluate the effects of serum samples on chlamydial growth, cells were seeded onto 6-well plates and cultured overnight to 90\% confluency. Elementary body (EB) stocks of C. trachomatis L2 (strain 434/Bu) (CtL2) and C. muridarum (strain Nigg) (Cm) [13] were diluted in DMEM containing 5\% serum samples and $1 \mu \mathrm{g} / \mathrm{ml}$ cycloheximide, which promotes chlamydial growth by inhibiting host cellular protein synthesis. To infect the cells, the overnight culture media were replaced with the EB-containing medium $(2 \mathrm{ml} /$ well). The multiplicity of infection was 0.5 inclusionforming unit (IFU) per cell. After culture at $37^{\circ} \mathrm{C}$ for $30 \mathrm{~h}$ $(\mathrm{Cm})$ or $36 \mathrm{~h}(\mathrm{CtL} 2)$, the culture media were replaced with $100 \mu \mathrm{L}$ of sucrose-phosphate-glutamate buffer, and cells were detached from the plastic surface using a Cell Lifter, and collected into a $5 \mathrm{ml}$ culture tube. Tubes were then placed on ice and subject to brief sonication to release chlamydiae from cells [13]. The sonicated harvests were serially diluted in a 1:10 manner and then inoculated onto L929 monolayers grown on 96 well plates, which were fixed with cold methanol following $30 \mathrm{~h}(\mathrm{Cm})$ or $36 \mathrm{~h}$ (CtL2) incubation at $37^{\circ} \mathrm{C}$. Cm and CtL2 inclusions were reacted with a mouse polyclonal anti-Cm antibody [14] and a monoclonal anti-major outer membrane protein antibody (clone L2-1-5) [15], respectively, followed by fluorescein isothiocyanate-conjugated rabbit anti-mouse IgG (Sigma-Aldrich). Inclusions were scored under an Olympic IX51 fluorescence microscope.

\section{Results}

We tested a total of 5 serum samples from commercial sources along with a control fetal bovine serum (CFBS) on the growth of $C$. trachomatis $\mathrm{L} 2$ (CtL2) and $C$. muridarum $(\mathrm{Cm})$. Among the five serum samples, three were fetal bovine sera (i.e., FBS1-3), one was a newborn calf serum (i.e., NBCS1), and the last one was known as animal serum complex (i.e., ASC1), of which the compositions were not disclosed by the manufacturer. CFBS had been tested previously and used for culturing both $\mathrm{Ct}$ and $\mathrm{Cm}$ for more than a year in our lab prior to this work. Compared with CFBS, FBS1 or NBCS1 demonstrated similar and the most desirable effect on CtL2 growth, resulting in the highest EB yields (Fig. 1a). FBS2 showed a slight $21 \%$ decrease in EB production, which was deemed statistically insignificant $(P=0.009)$. FBS3 and ASC1 demonstrated suboptimal effects on chlamydial growth, resulting in statistically significant $41 \%$ and $40 \%$ decreases, respectively, in EB production (Fig. 1a).

Compared to CtL2, Cm displayed mostly contrasting responses to the serum products (Fig. 1b). Among all samples tested, only FBS2 showed a similar effect on $\mathrm{Cm}$ growth as CFBS. FBS1, which was optimal for CtL2 growth, was suboptimal for $\mathrm{Cm}$, resulting in only $68 \%$ progeny EBs, compared to CFBS. Most interestingly, NBCS1, which was optimal for CtL2 growth, had the most detrimental effect on $\mathrm{Cm}$ growth, resulting in a 90\% EB production inhibition. FBS3, which had a suboptimal effect on CtL2 growth, displayed a similarly severe adverse effect as NBCS1, leading to an $88 \%$ reduction in EB production. ASC1, which had

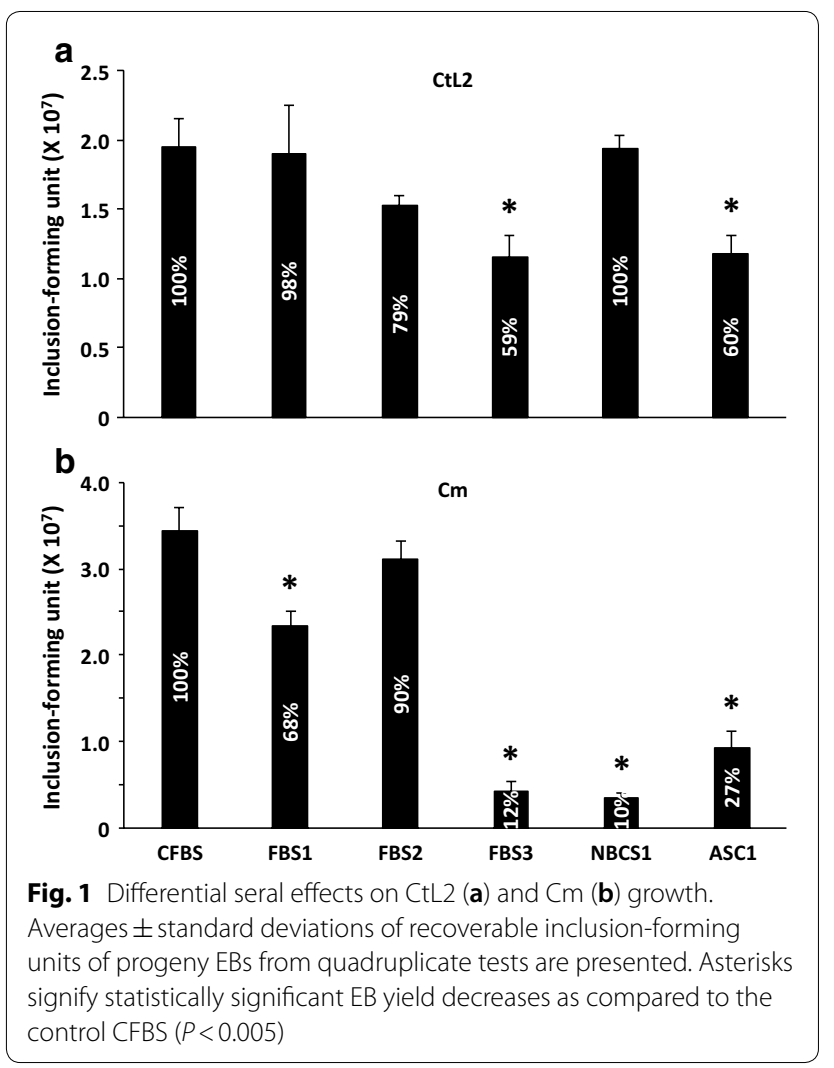


a suboptimal effect on CtL2 growth (40\% inhibition in EB yield), exhibited a more severe adverse effect on $\mathrm{Cm}$ growth, giving rise to a $73 \%$ decrease.

\section{Discussion}

The importance of serum in culturing chlamydiae was recognized starting more than four decades ago (e.g., [2, $3]$ ). However, previous studies reporting effects of different serum products on chlamydial growth were performed with only single species [2-5]. In this work, we have demonstrated that some animal sera have significantly different effects on $\mathrm{Ct}$ and $\mathrm{Cm}$ growth. Although we have not determined the underlying mechanism, we suspect anti-chlamydia antibodies are responsible for the observed inhibitory effects. $\mathrm{Ct}$ and $\mathrm{Cm}$ are known to infect only human and mouse, respectively. However, multiple other Chlamydia species, namely C. pecorum and C. abortus, C. pneumoniae, C. psittaci and C. gallinacean are known to infect cows $[9,16]$. Thus, it should not be surprising if FBS or NBCS contains anti-chlamydia antibodies because maternal IgG is capable of entering the fetal blood stream. Although genomes of Chlamydia species are highly conserved, they express different polymorphic proteins on the cell surface. These proteins serve as immunodominant antigens, which induce hosts to produce neutralizing antibodies $[17,18]$. Other outer membrane proteins including the major outer membrane protein are also immunodominant proteins [19]. Thus, the effects of a particular serum on $\mathrm{Ct}$ and $\mathrm{Cm}$ would be determined by antibodies with cross reactivity for the organisms (or not).

Surface-exposed domains of the major outer membrane protein are immunodominant epitopes [20, 21]. They are highly variable even within the same Chlamydia species [20,21]. While our findings mandate serum testing for individual Chlamydia species for optimal cultivation, tests may be necessary for individual serovars of Chlamydia species capable of infecting cows. Perhaps, serum testing should be performed for individual strains of Chlamydia species without well-established serovars.

\section{Limitations}

We make the recommendation of serum testing on individual Chlamydia species on the basis of data presented in Fig. 1. However, the suggestion of serum testing for different serovars or strains within some animal chlamydial species is made without experimental evidence.

\section{Abbreviations}

ASC: animal serum complex; CF: control fetal bovine serum; Cm: Chlamydia muridarum; CtL2: Chlamydia trachomatis serovar L2; DMEM: Dulbecco's
Modified Eagle Medium; FBS: fetal bovine serum; IFU: inclusion forming unit; NBCS: newborn calf serum.

\section{Acknowledgements}

We thank Dr. Harlan D. Caldwell (National Institute of Allergy and Infectious

Diseases) for supplying the L2-1-5 antibody.

\section{Authors' contributions}

All authors (MD, $\mathrm{HZ}$ and $\mathrm{HF}$ ) participated in the experimental design. MD and $\mathrm{HZ}$ performed the experiments. MD wrote the first draft of the manuscript, which was reviewed and edited first by $\mathrm{HZ}$ and $\mathrm{HF}$, and then by MD. All authors read and approved the final manuscript.

\section{Funding}

This work was supported by the National Institutes of Health (Grant \# Al140167), and New Jersey Health Foundation (Grant \# PC 20-18). The funders played no role in the study design, execution and publication.

\section{Availability of data and materials}

The dataset used for this study is available from the corresponding author on request.

Ethics approval and consent to participate Not applicable.

\section{Consent for publication}

Not applicable.

\section{Competing interests}

The authors declare that they have no competing interests.

\section{Author details}

${ }^{1}$ Department of Pharmacology, Robert Wood Johnson Medical School, Rutgers University, Piscataway, NJ, USA. ${ }^{2}$ Graduate Program in Physiology and Integrative Biology, School of Graduate Studies, Piscataway, NJ, USA.

Received: 19 September 2019 Accepted: 4 January 2020

Published online: 13 January 2020

\section{References}

1. Yao T, Asayama Y. Animal-cell culture media: history, characteristics, and current issues. Reprod Med Biol. 2017;16(2):99-117.

2. Allan I, Pearce JH. Serum modulation of cell susceptibility to chlamydial infection. FEMS Microbiol Lett. 1977;1(4):211-3.

3. Karayiannis P. HOBSON D: the role of calf serum in the growth of Chlamydia trachomatis in McCoy cell cultures. Microbiology. 1981;122(1):47-54.

4. LaScolea $L \mathrm{Jr}$, Baldigo SM. Infectivity of Chlamydia trachomatis in tissue culture with newborn calf serum. J Clin Microbiol. 1982;15(5):951-3.

5. Levy NJ, Benes S, McCormack WM. Growth of host cells and Chlamydia trachomatis in medium containing serum from 16-week-old calves. J Clin Microbiol. 1983;17(1):68-71.

6. Borel N, Greub G. International Committee on Systematics of Prokaryotes (ICSP) Subcommittee on the taxonomy of Chlamydiae. Minutes of the closed meeting, 5 July 2018, Woudschoten, Zeist, The Netherlands. Int J Syst Evol Microbiol. 2019;69(8):2606-8

7. WHO: Global prevalence and incidence of selected curable sexually transmitted infections: Overview and estimates. 2001.

8. Kalayoglu MV, Libby P, Byrne Gl. Chlamydia pneumoniae as an emerging risk factor in cardiovascular disease. JAMA. 2002;288(21):2724-31.

9. Cheong HC, Lee CYQ, Cheok YY, Tan GMY, Looi CY, Wong WF. Chlamydiaceae: diseases in primary hosts and zoonosis. Microorganisms. 2019;7(5):146.

10. Zhong G. Chlamydia spreading from the genital tract to the gastrointestinal tract-a two-hit hypothesis. Trends Microbiol. 2018;26(7):611-23.

11. de la Maza L, Pal S, Khamesipour A, Peterson E. Intravaginal inoculation of mice with the Chlamydia trachomatis mouse pneumonitis biovar results in infertility. Infect Immun. 1994;62(5):2094-7. 
12. Yang Z, Conrad T, Zhou Z, Chen J, Dutow P, Klos A, Zhong G. Complement factor $C 5$ but not $C 3$ contributes significantly to hydrosalpinx development in mice infected with Chlamydia muridarum. Infect Immun. 2014;82(8):3154-63.

13. Bao X, Gylfe A, Sturdevant GL, Gong Z, Xu S, Caldwell HD, Elofsson M, Fan H. Benzylidene acylhydrazides inhibit chlamydial growth in a type III secretion- and iron chelation-independent manner. J Bacteriol. 2014;196(16):2989-3001.

14. Zhang $\mathrm{H}$, Kunadia $\mathrm{A}$, Lin $Y$, Fondell JD, Seidel $\mathrm{D}$, Fan $\mathrm{H}$. Identification of a strong and specific antichlamydial N-acylhydrazone. PLoS ONE. 2017;12(10):e0185783.

15. Zhang YX, Stewart SJ, Caldwell HD. Protective monoclonal antibodies to Chlamydia trachomatis serovar- and serogroup-specific major outer membrane protein determinants. Infect Immun. 1989;57(2):636-8.

16. Li J, Guo W, Kaltenboeck B, Sachse K, Yang Y, Lu G, Zhang J, Luan L, You J, Huang K, et al. Chlamydia pecorum is the endemic intestinal species in cattle while C. gallinacea, C. psittaci and C. pneumoniae associate with sporadic systemic infection. Vet Microbiol. 2016;193:93-9.

17. Crane DD, Carlson JH, Fischer ER, Bavoil P, Hsia RC, Tan C, Kuo CC, Caldwell $\mathrm{HD}$. Chlamydia trachomatis polymorphic membrane protein $\mathrm{D}$ is a species-common pan-neutralizing antigen. Proc Natl Acad Sci U S A. 2006;103(6):1894-9.

18. Tan C, Hsia RC, Shou H, Haggerty CL, Ness RB, Gaydos CA, Dean D, Scurlock AM, Wilson DP, Bavoil PM. Chlamydia trachomatis-infected patients display variable antibody profiles against the nine-member polymorphic membrane protein family. Infect Immun. 2009;77(8):3218-26.

19. Caldwell HD, Perry LJ. Neutralization of Chlamydia trachomatis infectivity with antibodies to the major outer membrane protein. Infect Immun. 1982;38(2):745-54

20. Zhang YX, Stewart S, Joseph T, Taylor HR, Caldwell HD. Protective monoclonal antibodies recognize epitopes located on the major outer membrane protein of Chlamydia trachomatis. J Immunol. 1987;138(2):575-81.

21. Zhong G, Berry J, Brunham RC. Antibody recognition of a neutralization epitope on the major outer membrane protein of Chlamydia trachomatis. Infect Immun. 1994;62(5):1576-83.

\section{Publisher's Note}

Springer Nature remains neutral with regard to jurisdictional claims in published maps and institutional affiliations.
Ready to submit your research? Choose BMC and benefit from:

- fast, convenient online submission

- thorough peer review by experienced researchers in your field

- rapid publication on acceptance

- support for research data, including large and complex data types

- gold Open Access which fosters wider collaboration and increased citations

- maximum visibility for your research: over $100 \mathrm{M}$ website views per year

At BMC, research is always in progress.

Learn more biomedcentral.com/submissions 